\title{
Edge Activator: Effect of Concentration Variation of Tween 80 on Characteristics and Rate of Difusion transfersome sodium diclofenac
}

\author{
Gabena Indrayani Dalimunthe ${ }^{1^{*}}$, Ricky Andi Syahputra2 \\ ${ }^{1}$ Department of Pharmacy, Universitas Muslim Nusantara Al Washiyah, Jalan Guru II Medan, Sumatra \\ Utara, Indonesia. \\ 2Department of Chemistry, Universitas Negeri Medan, Sumatra Utara, Indonesia \\ *Email: gabenaindrayani@yahoo.co.id
}

\section{ABSTRAK}

Natrium diklofenak adalah obat antiinflamasi non steroid yang bekerja dengan menghambat enzim siklooksigenase. Transfersom adalah sistem penghantaran transdermal yang terdiri dari fosfolipid dan edge activator, meningkatkan ukuran pori-pori lipid barrier stratum korneum masuk kedalam kulit melalui dorongan gerakan transbarrier dan memeras diri mengikuti ukuran pori lipid barrier. Tujuan dari penelitian ini adalah untuk mengetahui pengaruh konsentrasi tween- 80 sebagai edge activator terhadap karakteristik dan laju difusi transfersom natrium diklofenak. Preparasi transfersom menggunakan metode vorteks-sonikasi yang dibuat dalam 5 formula dengan variasi perbandingan konsentrasi fosfatidilkolin dan tween- 80 (95:05, 90:10, 85:15, 80:20, dan 75:25). Hasil penelitian menunjukan bahwa ke-5 formula memiliki bentuk morfologi yang berbeda. Dari hasil uji statistik menggunakan One-Way ANOVA menunjukan bahwa terdapat pengaruh yang bermakna ( $\mathrm{p}$ value 0.01 ) dari konsentrasi edge-activator terhadap laju difusi transfersom natrium diklofenak.

\section{Kata Kunci:}

Transfersom, Natrium Diklofenak, Edge Activator, Transdermal

$\begin{array}{lcc}\text { Diterima: } & \text { Disetujui: } & \text { Online: } \\ 04-10-2021 & 08-11-2021 & 08-11-2021\end{array}$

\section{ABSTRACT}

Diclofenac sodium is a Transfersom is a transdermal delivery system consisting of phospholipids and edge activators. Transfersom increases the size of the stratum corneum lipid barrier pores, then enters the skin through the drive of the trans-barrier motion and squeezes itself to follow the lipid barrier pore size. The purpose of this study is to determine the effect of the tween- 80 concentration as an edge activator on the characteristics and diffusion rate of diclofenac sodium transfersom. Transferom preparation used the vortex-sonication method which was made in five formulae with variations in the concentration ratio of phosphatidylcholine and tween-80 (95:05, 90:10, 85:15, 80:20, and 75:25). The results show that all five formulae have different morphological forms. The results of statistical tests using OneWay ANOVA finds a significant effect ( $p$-value) of the edge activator concentration on the diffusion rate of diclofenac sodium transfersom.

Copyright ( $\odot 2021$ Jsscr. All rights reserved.

Keywords:

Transfersomes, Diclofenac Sodium, Edge Activator, Transdermal

\begin{tabular}{ccc}
\hline Received: & Accepted: & Online: \\
2021-10-04 & $2021-11-08$ & $2021-11-08$ \\
\hline
\end{tabular}




\section{Pendahuluan}

Inflamasi merupakan gangguan pada membran sel yang menyebabkan fosfolipid mengeluarkan asam arakidonat dengan bantuan enzim fosfolipase kemudian diubah menjadi mediator-mediator nyeri. Natrium diklofenak adalah antiinflmasi non steroid yang bekerja dengan cara menghambat enzim Sikooksigenase-2 yang dapat berubah menjadi mediator inflamasi. Pemberian natrium diklofenak secara oral dapat menyebabkan efek samping terhadap gastrointestinal dan kardiovaskular. Selain itu, lima puluh persen $(50 \%)$ diklofenak dosis oral tidak mencapai sirkulasi sistemik karena efek metabolisme lintas pertama. Natrium diklofenak akan diperburuk proses absorbsinya oleh makanan. Ikatan protein 99,7\% sehingga kurangnya jumlah obat bebas yang dapat memberikan efek. Untuk dapat meningkatkan efikasi dan efek terapeutik, natrium diklofenak dapat diformulasikan dalam bentuk sediaan transdermal.

Transfersom merupakan agregat kompleks yang meningkatkan ukuran pori hidrofilik kulit sehingga dapat melalui Stratum corneum yang merupakan penghalang obat untuk masuk kedalam kulit. Transfersom mengatasi kesulitan penetrasi kulit dengan memeras diri di sepanjang lipatan penyegelan intraseluler dari stratum korneum. Aktivator tepi adalah komponen transfersom sebagai pelembut bilayer, meningkatkan fleksibilitas dan permeabilitas bilayer lipid. Surfaktan secara proporsional meningkatkan fluiditas membran dan meningkatkan penetrasi melalui kulit. Tween 80 dan Span 80 adalah kedua jenis surfaktan non-ionik yang dapat menembus dengan cepat dan mencapai lebih dalam dari lapisan stratum korneum [6][7].

Natrium diklofenak bersifat sedikit hidrofilik sehingga berdasarkan hal tersebut, maka dilakukan penelitian pengaruh tween-80 yang bersifat hidrofilik sebagai Edge activator transfersom natrium diklofenak terhadap karakteristik dan laju difusinya.

\section{Metode}

Penelitian ini merupakan penelitian eksperimental laboratorium, yaitu untuk memformulasikan vesikel transfersom natrium diklofenak sebagai sistem penghantaran transdermal dan uji laju difusi menggunakan sel difusi Franz.

\section{Alat dan Bahan}

Alat yang digunakan yaitu eppendorf, gelas beker, gelas ukur, hot plate, hitter, pengaduk magnetik (Biosan), mikro pipet (Eppendorf research plus, Germany), mikroskop digital (Dino lite), neraca analitik, particle size analyser (Delsatm nano c, Beckman Coulter), pipet tetes, sel difusi franz, setrifuse, sonikator, spektrofotometer uv-vis (Perkin-elmer, Singapore), stirrer, syringe $5 \mathrm{ml}$ (Terumo corp, Philipina), termometer, timbangan analitik (A\&D Company), ultrasonikasi, ultrasentrifugasi (Centurion scientific c2 series, Uk), vial. Bahan yang digunakan yaitu aquades, fosfatidilkolin, kalium dihidrogen fosfat, natium hidroksida, natrium diklofenak, tween 80 .

\section{Pembuatan Transfersom Natrium Diklofenak}

Transfersom dibuat dengan mencampurkan fosfatidilkolin dan tween-80 dalam dapar fosfat pH 7.4. Natrium Diklofenak ditambahkan setelah diperoleh suspensi lipid. Setelah itu dilakukan pengadukan konstan $500 \mathrm{rpm}$ selama 5 menit lalu disonikasi selama 30 menit [8]. 


\section{Pengamatan Bentuk Morfologi Vesikel}

Suspensi transfersom diletak-kan di atas permukaan kaca objek. Bentuk dan ukuran vesikel diamati dengan menggunakan mikroskop optic [9].

\section{Pengukuran Efisiensi Penjerapan}

Efisiensi penjerapan ditentukan dengan mengukur konsentrasi obat bebas yang tidak terikat dalam media air. Sejumlah transferom ditempatkan dalam tabung eppendorf dan disentrifugasi $6.000 \mathrm{rpm}$ selama 30 menit. Diambil supernatan lalu diukur kadar menggunakan spektrofotometer uv-vis pada panjang gelombang $277 \mathrm{~nm}$. Efisiensi penjerapan dapat dihitung menggunakan rumus:

$$
\% E E=\frac{\mathrm{Qt}-\mathrm{Qs}}{\mathrm{Qt}} \times 100 \%
$$

\section{Penentuan Ukuran Partikel}

Penentuan ukuran partikel dilakukan dengan menggunakan PSA (Particle Size Analyzer). Metode ini dilakukan berdasarkan difraksi sinar laser ukuran partikel dari ukuran submikron sampai millimeter, fluktuasi atau hamburan intensitas cahaya oleh pergerakan partikel yang terdifusi atau tersebar [10].

\section{Uji Laju Difusi Transfersom Natrium Diklofenak secara In Vitro}

Uji laju difusi dilakukan dengan menggunakan membran kulit ular yang telah di hidrasi selama 30 menit. Kemudian, kompartemen reseptor diisi dengan dapar fosfat $\mathrm{pH}$ 7,4 dan dijaga suhu $37 \pm 1^{\circ} \mathrm{C}$, serta diaduk dengan stirrer berkecepatan konstan. Kemudian kulit ular diletakkan di antara kompartemen donor dan kompartemen reseptor dengan posisi stratum korneum menghadap ke atas. $1 \mathrm{~mL}$ suspensi transfersom diaplikasikan pada permukaan kulit. Kemudian, pada menit ke 30, 60, 90, dan 120 dilakukan sampling sebanyak $3 \mathrm{~mL}$ dan digantikan dengan sejumlah volume yang sama. Sampel diukur serapannya pada panjang gelombang $277 \mathrm{~nm}$ dengan menggunakan spektrofotometer UV-Vis.

\section{Analisis Data}

Data hubungan antara masing-masing formulasi dengan presentasi natrium diklofenak terpenetrasi di analisis secara statistik dengan metode One Way ANOVA (Analysis of Variance) dengan taraf kepercayaan 99\%. Dipilih metode ini karena variabel terikat dan variabel bebas berjumlah satu dimana variabel bebas adalah konsentrasi tween- 80 dan variabel terikatnya adalah fluks atau laju difusi.

\section{Hasil dan Pembahasan}

1. Morfologi Vesikel Transfersom Natrium Diklofenak

Tabel 2. Bentuk vesikel transfersom natrium diklofenak

\begin{tabular}{cc}
\hline Formula & Bentuk \\
\hline F1 & $\begin{array}{c}\text { Besar dan kecil; bulat tidak beraturan dan ada yang berbentuk } \\
\text { jarum; menumpuk sedikit }\end{array}$ \\
\hline F2 & Sedang dan kecil; bulat tak beraturan; menumpuk agak banyak \\
\hline F3 & Sedang dan kecil; bulat tak beraturan; menumpuk dan banyak \\
\hline
\end{tabular}




\begin{tabular}{cc}
\hline F4 & Besar dan kecil; bulat tak beraturan; menumpuk agak banyak \\
\hline F5 & Sedang dan kecil; bulat tak beraturan; menumpuk sedikit \\
\hline
\end{tabular}

Berdasarkan tabel diatas dapat diketahui bahwa kelima formula memiliki bentuk dan jumlah yang berbeda. Dari kelima formula yang memiliki jumlah vesikel terbanyak adalah formula 3.

\section{Penentuan Distribusi dan Ukuran Vesikel Transfersom Natrium Diklofenak}

Tabel 3. Penentuan distribusi dan ukuran vesikel transfersom

\begin{tabular}{ccc}
\hline Formula & Indeks Polidispersitas & Ukuran $(\mathrm{nm})$ \\
\hline F3 & 0,265 & 617 \\
\hline
\end{tabular}

Penentuan distribusi dan ukuran dengan Particle Size Analizer. Berdasarkan tabel 5 dapat dilihat bahwa distribusi ukuran partikel berdasarkan indeks polidispersitasnya adalah 0.265 sedangkan ukuran partikelnya adalah $617 \mathrm{~nm}$.

\section{Penentuan Efisiensi Penjerapan}

Tabel 4. Efisiensi penjerapan transfersom natrium diklofenak

\begin{tabular}{ccc}
\hline Formula & $\begin{array}{c}\text { Rasio Perbandingan } \\
\text { PC : EA }\end{array}$ & \% Efisiensi Penjerapan \\
\hline F1 & $95: 05$ & 92.83 \\
\hline F2 & $90: 10$ & 93.04 \\
\hline F3 & $85: 15$ & 93.67 \\
\hline F4 & $80: 20$ & 92.36 \\
\hline F5 & $75: 25$ & 91.36 \\
\hline
\end{tabular}

Berdasarkan tabel 6 dapat dilihat bahwa formula 3 memiliki persentase efisiensi penjerapan tertinggi yaitu $93,67 \%$.

6. Uji Penetrasi Natrium Diklofenak dalam Vesikel Transfersom

Tabel 5. Hasil rerata vesikel transfersom natrium diklofenak

\begin{tabular}{cccc}
\hline Formula & $\begin{array}{c}\text { Jumlah Kumulatif } \\
\text { Terpenetrasi } \\
\left(\mu \mathrm{g} / \mathrm{cm}^{2}\right)\end{array}$ & $\begin{array}{c}\text { Persen Penetrasi } \\
(\%)\end{array}$ & $\begin{array}{c}\text { Laju Penetrasi } \\
\left(\mu \mathrm{g} / \mathrm{cm}^{2} / \mathrm{Jam}\right)\end{array}$ \\
\hline F1 & 27,21 & 1,09 & 13,61 \\
F2 & 33,8 & 1,35 & 16,9 \\
F3 & 73,35 & 2,93 & 36,68 \\
F4 & 38,29 & 1,49 & 19,15 \\
F5 & 28,82 & 1,15 & 14,42 \\
\hline
\end{tabular}

Berdasarkan tabel 4.9 diatas dapat dilihat bahwa jumlah kumulatif, persen terpenetrasi, dan laju penetrasi tertinggi dimiliki oleh formula 3 dengan jumlah kumulatif terpenetrasi $73,35 \mu \mathrm{g} / \mathrm{cm}^{2}$, persen terpenetrasi $2,93 \%$ dan laju penetrasi $(36,68$ $\left.\mu \mathrm{g} / \mathrm{cm}^{2} / \mathrm{Jam}\right)$. 


\section{Uji One Way-Anova}

Hasil uji secara statistik yang didapatkan adalah memenuhi perbedaan yang signifikan dimana nilai $\mathrm{p}$ ( $\mathrm{p}$ Value) kurang dari bias $1 \%(\mathrm{\alpha}=0.01)$ yaitu 0.000 , variansi distribusi data yang signifikan yang ditandai dengan nilai sign. lebih besar $(\alpha=0.01)$ yaitu 0,097 , serta homogenitas data yang juga signifikan yang ditandai dengan nilai sig lebih besar $(\alpha=0.01)$ yaitu 0,235 .

\section{Pembahasan}

Pembuatan kurva baku natrium diklofenak bertujuan untuk mendapatkan persamaan garis yang linear $\mathrm{y}=\mathrm{a}+\mathrm{bx}$ yang berfungsi untuk menghitung jumlah kadar konsentrasi natrium diklofenak didalam sampel. Hasil absorbansi kemudian diregresikan terhadap konsnetrasi yang menghasilkan persamaan garis $\mathrm{y}=0.0225 \mathrm{x}+0.0019$ dengan nilai korelasi linieritas $r=0,997$, nilai intersep $a=0.0019$ dan nilai slop $b=0.0225$. Kurva pada gambar 1 menunjukan grafik linear artinya setiap peningkatan nilai konsentrasi diikuti dengan meningkatnya nilai absorbansi.

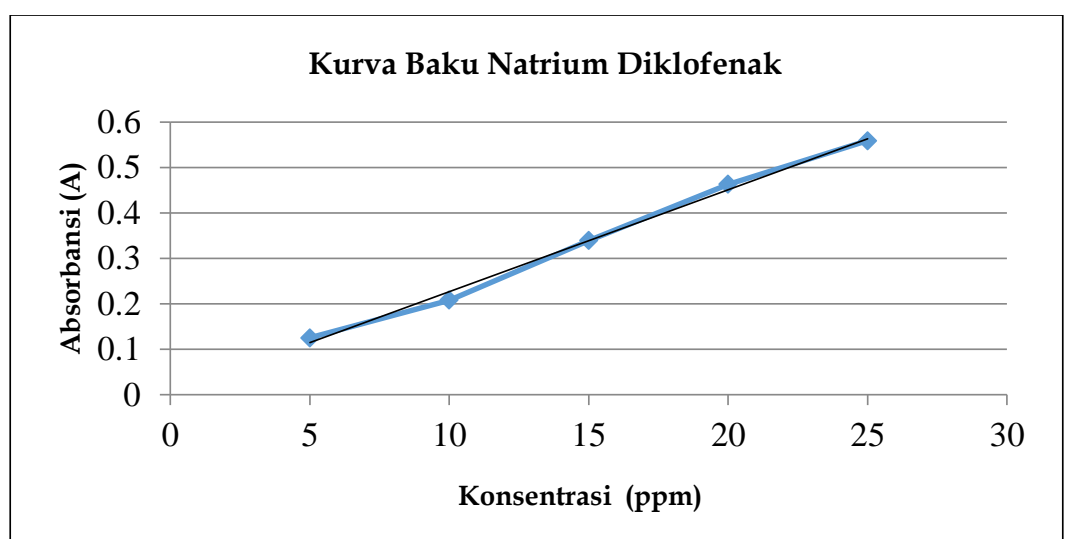

Gambar 1. Grafik Kurva Baku Natrium Diklofenak dalam Dapar Fosfat pH 7.4

Preparasi transfersom dilakukan dengan metode vortex-sonikasi karena sederhana dan cepat dalam pengerjaan. Fosfatidilkolin dan tween-80 dicampurkan lalu dihidrasi dengan dapar fosfat $\mathrm{pH} 7.4$ hingga $10 \mathrm{~mL}$. Hidrasi bertujuan untuk membentuk struktur lamellar yang membentuk bilayer seperti bola. Untuk menghomogenkan cairan yang terbentuk, digunakan pengaduk motor listrik dengan kecepatan $500 \mathrm{rpm}$ selama 5 menit. Kemudian untuk memperkecil ukuran partikel digunakan sonikator selama 30 menit. Energi ultrasonik pada sonikator akan memecah ikatan antar molekul sehingga menghasilkan ukuran vesikel yang lebih kecil [10][12].

Pengujian morfologi vesikel transfersom natrium diklofenak dilakukan dengan menggunakan mikroskop cahaya dengan perbesaran 100 kali. Adanya transfersom yang menumpuk ini disebabkan karena fosfatidilkolin tidak hanya membentuk cross link antar partikel dalam satu nanopartikel tetapi juga membentuk cross link antara nanopartikel satu dengan nanopartikel yang lain sehingga nanopartikel saling bergabung membentuk ukuran yang lebih besar [13]. 


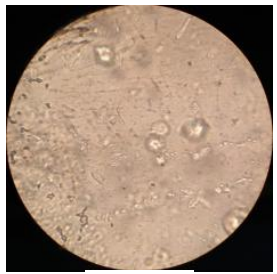

(a)

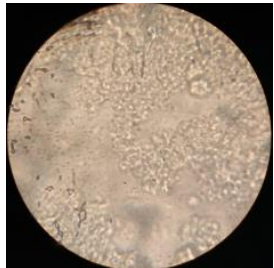

(b)

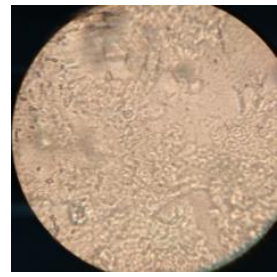

(c)

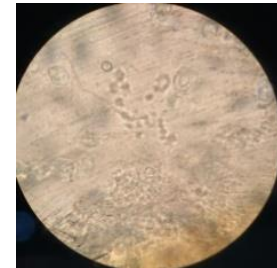

(d)

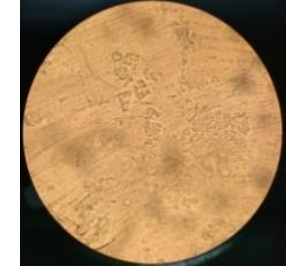

(e)

Gambar 2. Bentuk Vesikel Transfersom Natrium Diklofenak (a) Formula 1; (b) Formula 2; (c) Formula 3; (d) Formula 4; (e) Formula 5

Penentuan distribusi dan ukuran partikel dilakukan dengan menggunakan PSA atau Particle Size Analyzer. Prinsipnya berdasarkan hamburan cahaya laser oleh partikelpartikel dalam sampel. Distribusi ukuran partikel dinyatakan sebagai indeks polidispersitas. Indeks polidispersitas berfungsi untuk menentukan kestabilan fisik suatu sistem dispersi. Berdasarkan tabel tersebut dapat diketahui bahwa indeks polidispersitas dari formula 3 adalah 0,265. Rentang nilai indeks polidispersitas yang dapat diterima adalah 0 sampai 0,5 . Nilai indeks polidispersitas yang rendah menunjukan bahwa sistem dispersi yang terbentuk bersifat lebih stabil untuk jangka panjang. Ukuran partikel transfersom natrium diklofenak pada formula 3 yaitu $617 \mathrm{~nm}$. Vesikel dengan ukuran tersebut merupakan jenis vesikel LUV (Large Unilamellar Vesicles). vesikel LUV adalah vesikel yang memiliki ukuran partikel lebih dari $100 \mathrm{~nm}$ sampai $1000 \mathrm{~nm}$ [14].

Berdasarkan kurva pada gambar 3, formula 3 memiliki jumlah kumulatif yang sangat signifikan dibandingkan dengan formula lainnya. Hal tersebut disebabkan karena perbandingan konsentrasi antara fosfatidilkolin dan tween-80 yang proporsional terdapat pada formula 3. Hal ini sesuai dengan Ghada $M$ et al (2010), deformabilitas transfersom tergantung pada komposisi edge activator yang digunakan. Aktivator tepi adalah komponen pelembut bilayer, seperti surfaktan biokompatibel yang berfungsi meningkatkan fleksibilitas dan permeabilitas bilayer lipid. Konsentrasi tween-80 yang terlalu tinggi dapat menyebabkan transfersom kehilangan struktur vesikelnya karena pembentukan misel yang berlebihan. Sebaliknya konsentrasi tween-80 yang rendah akan menyebabkan pembentukan struktur vesikel yang kaku sehingga sulit untuk terdeformasi dan menyesuaikan dengan ukuran dari lipid barrier stratum korneum. [6][15].

Persen terpenetrasi berbanding lurus dengan jumlah kumulatif. Semakin tinggi jumlah kumulatif maka semakin tinggi pula persen terpenetrasi. Berdasarkan kurva pada gambar 4 dapat dilihat bahwa persen terpenetrasi tertinggi dimiliki oleh formula 3. 


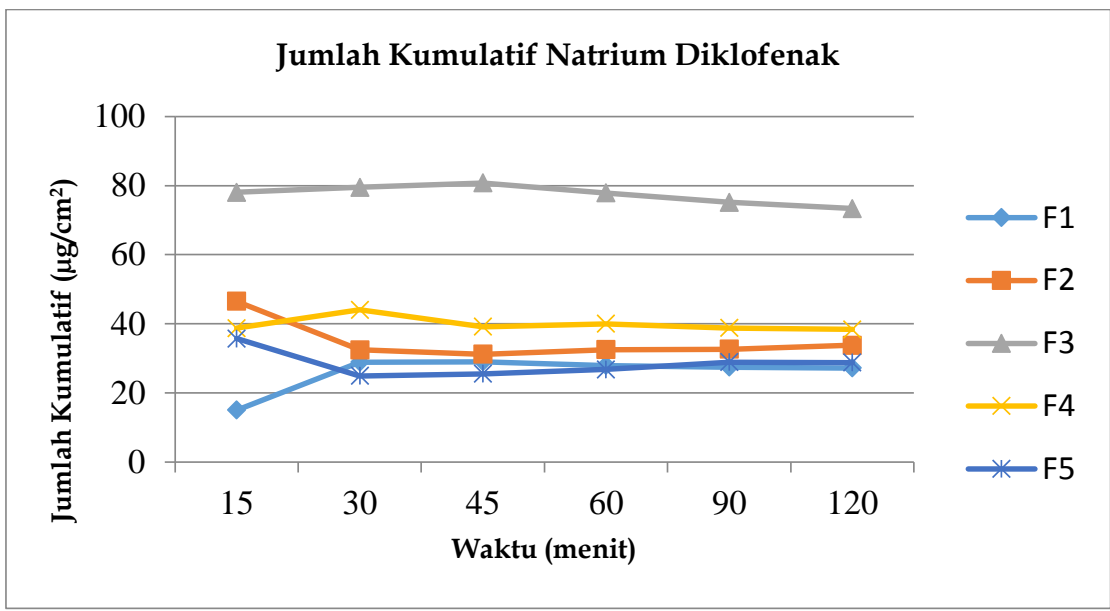

Gambar 3. Kurva jumlah kumulatif natrium diklofenak yang terpenetrasi

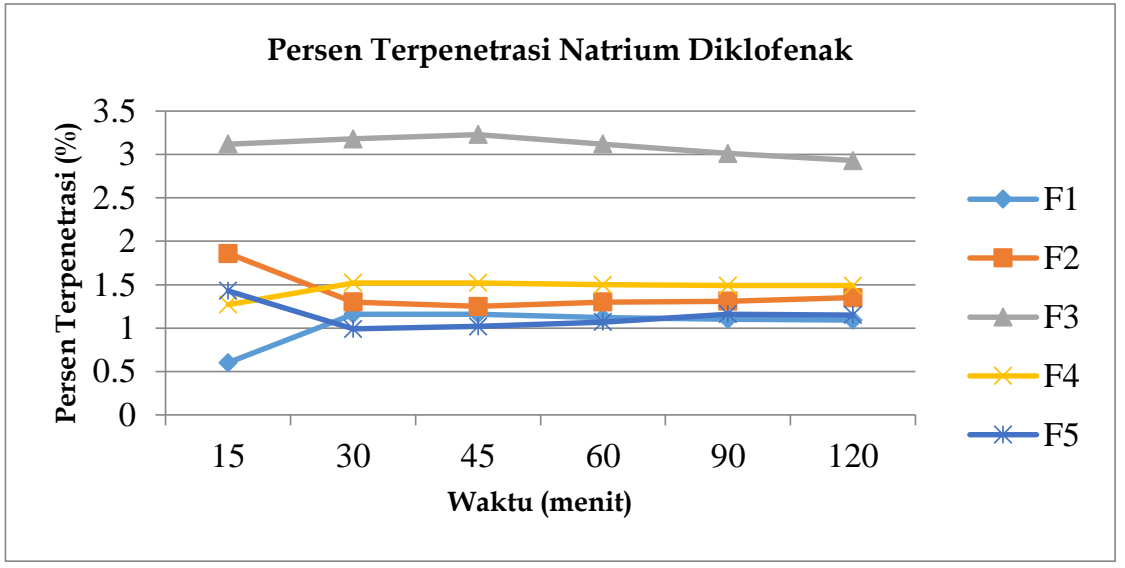

Gambar 4. Kurva persen natrium diklofenak yang terpenetrasi

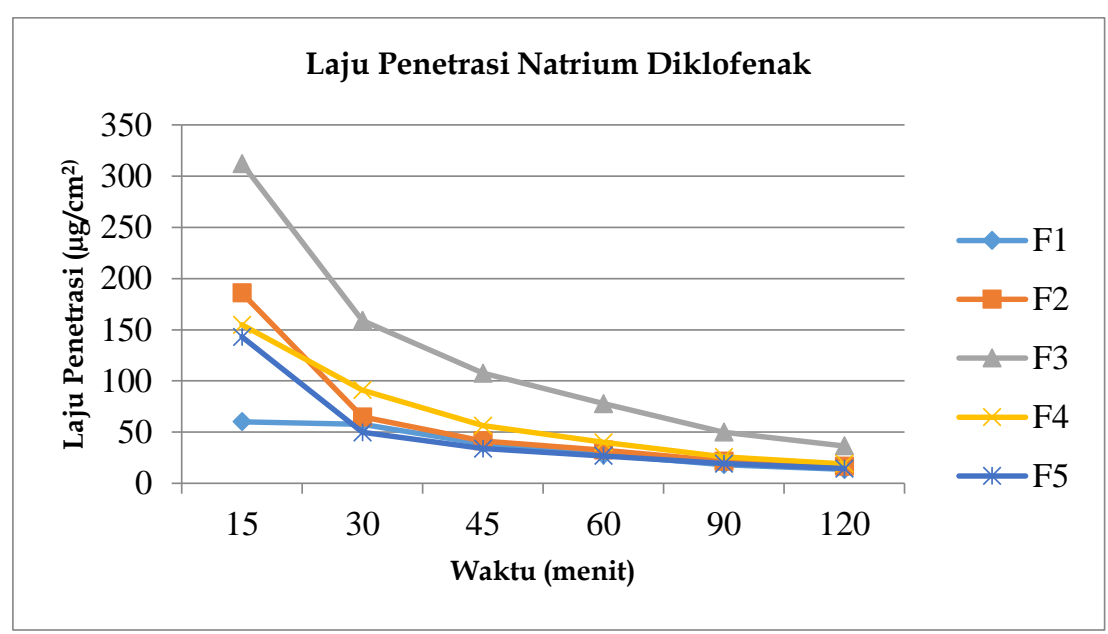

Gambar 5. Kurva laju penetrasi transfersom natrium diklofenak

Berdasarkan hasil analisis One Way - Anova dapat diamati nilai P atau sig. sebesar 0.000 dengan nilai $\mathrm{a}=0.01$, hal ini menunjukkan bahwa nilai $\mathrm{P}$ lebih rendah dibandingkan dengan nilai a (Ho ditolak), sehingga dapat disimpulkan bahwa perbedaan konsentrasi tween-80 sebagai edge activator dalam transfersom natrium diklofenak dapat berpengaruh pada laju penetrasinya. 


\section{Kesimpulan}

Terdapat pengaruh konsentrasi tween-80 sebagai edge activator terhadap karakteristik transfersom natrium diklofenak meliputi morfologi vesikel, ukuran partikel dan efisiensi penjerapan. Konsentrasi tween- 80 sebagai edge activator dapat mempengaruhi laju difusi transfersom natrium diklofenak.

\section{Referensi}

[1] Multazar, A., Nursiah, S., Rambe, A., dan Harahap, Ida S., 2012. Ekspresi cyclooxygenase-2 (COX-2). ORLI

[2] Tan Hoan, Tjay, dan Kirana Rahardja. 2007. Obat-Obat Penting Khasiat, Penggunaan dan Efek-Efek Sampingnya. Edisi Keenam. Jakarta: PT. Elex Media Komputindo

[3] Amit K N, B Mohanty, and Kalyan K S. 2010. Comparative Evaluation Of in Vitro Diclofenac Sodium Permeability Across Excised Mouse Skin From Different Common Pharmaceutical Vehicles. International Journal of PharmTech Research

[4] J. V. Willis, M. J. Kendall, R. M. Flinn, D. P. Thornhill, P. G. Welling. 1979. The Pharmacokinetics of Diclofenac Sodium Following Intravenous and Oral Administration. Eur J Clin Pharmacol

[5] Merin P. Eldhose, Flowerlet Mathew, Neethusha J. Mathew. 2016. Transfersomes: A Review. International Journal Of Pharmacy And Pharmaceutical Research.

[6] Jacob L, Anoop KR. 2013. A Review On Surfactants As Edge Activator In Ultradeformable Vesicles For Enhanced Skin Delivery. Int J Pharm Bio Sci.

[7] Wiranti Anggraini, Erny Sagita, Iskandarsyah Iskandarsyah. 2017. Effect Of Hydrophilicity Surfactants Toward Characterization And In Vitro Transfersomes Penetration In Gels Using Franz Diffusion Test. International Journal of Applied Pharmaceutics.

[8] Wu, Pey-Shiuan \& Li, Yu-Syuan \& Kuo, Yi-Ching \& Tsai, Suh-Jen \& Lin, ChihChien. 2019. Preparation and Evaluation of Novel Transfersomes Combined with the Natural Antioxidant Resveratrol. Molecules.

[9] Akib, Halimahtussaddiyah dan Prawesti. 2014. Preparasi Fenilbutazon dalam Pembawa Vesikular Etosom dengan Berbagai Variasi Konsentrasi Fosfatidilkolin dan Etanol. Medula.

[10] Mohanraj, V.J., and Chen, Y. 2006. Nanoparticles - A Review. Tropical Journal of Pharmaceutical Research.

[11] Dali, S.M. 2015. Pengaruh Dimetil Sulfoksida (DMSO) terhadap Penetrasi Krim Asam Kojat secara In Vitro. Skripsi. Universitas Negeri Gorontalo. Gorontalo.

[12] Abolfazl Akbarzadeh, Rogaie Rezaei-Sadabady, Soodabeh Davaran, Sang Woo Joo, Nosratollah Zarghami, Younes Hanifehpour, Mohammad Samiei, Mohammad Kouhi and Kazem Nejati-Koshki. 2013. Liposome: Classification, Preparation, and Applications. Nanoscale Research Letters. 
[13] Sari, R. Permata. 2018. Formulasi dan Karakterisasi Fisetin Transfersom dengan Metode Hidrasi Lapis Tipis. Surakarta: Universitas Setia Budi

[14] Go'mez-Hens A, Manuel Ferna'ndez-Romero J. 2005. The Role of Liposomes in Analytical Processes. Trends Anal. Chem.

[15] Ghada M. El Zaafarany, Gehanne A.S. Awad, Samar M. Holayel, Nahed D. Mortada. 2010. Role of Edge Activators and Surface Charge in Developing Ultradeformable Vesicles with Enhanced Skin Delivery. International Journal of Pharmaceutics 